\title{
Characterization of sea lettuce (Ulva lactuca) from Matara, Sri Lanka and development of nutribars as a functional food
}

\author{
C. Udayangani ${ }^{1}$, I. Wijesekara ${ }^{1,2^{*}}$ and I. Wickramasinghe ${ }^{1}$ \\ ${ }^{I}$ Department of Food Science \& Technology, Faculty of Applied Sciences, University of Sri \\ Jayewardenepura, Gangodawila, Nugegoda, Sri Lanka \\ ${ }^{2}$ Centre for Marine Science \& Technology, Faculty of Applied Sciences, University of Sri \\ Jayewardenepura, Gangodawila, Nugegoda, Sri Lanka
}

*Correspondence: isuruw@sci.sjp.ac.lk; (1D https://orcid.org/0000-0003-1688-8801

Received: $29^{\text {th }}$ April 2019, Revised: $25^{\text {th }}$ September 2019, Accepted: $28^{\text {th }}$ October 2019

\begin{abstract}
Edible seaweed Ulva lactuca is a rich source of dietary fiber, protein, and minerals, but currently underutilized in Sri Lanka. In the present study, nutribars (composed of cereals and golden syrups) were developed incorporating dried $U$. lactuca powder (moisture content; $15.29 \pm$ $0.03 \%$, dry basis) at 5 and $10 \%(\mathrm{w} / \mathrm{w})$ ratios. Seaweeds were manually collected in July, 2017 from Matara, Sri Lanka, cleaned, and oven-dried at $60{ }^{\circ} \mathrm{C}$ for $8 \mathrm{~h}$. The proximate composition, crude ulvan content, swelling capacity, water holding capacity (WHC), and oil holding capacity (OHC) of powdered seaweed were evaluated. Further, crude protein content was estimated in 0 (control), 5 and $10 \%$ of seaweed incorporated nutribars. The crude protein content in dried $U$. lactuca was $20.16 \pm 0.16 \%$. The WHC of pulverized $U$. lactuca was $4.39 \pm 0.07 \mathrm{~g}$ of water per $\mathrm{g}$ of seaweed powder, and $\mathrm{OHC}$ was $2.22 \pm 0.27 \mathrm{~g} / \mathrm{g}$ at room temperature $\left(25^{\circ} \mathrm{C}\right)$. Significantly highest $(\mathrm{p}<0.05)$ protein content $(8.55 \pm 0.38 \%)$ was found for $10 \% \mathrm{U}$. lactuca added nutribar while it was $7.54 \%( \pm 0.15)$ and $7.89 \%( \pm 0.03)$ respectively for $0 \%$ and $5 \%$ seaweed added nutribars. Moreover, the sensory evaluation results revealed that the nutribars incorporated with $5 \%$ U. lactuca $(\mathrm{w} / \mathrm{w})$ was shown almost similar sensory profile as the control except colour. However, $10 \%$ U. lactuca (w/w) added nutribars contained higher protein content than the control but rejected in overall acceptability. Collectively, these results suggested that the under-utilized green seaweed $U$. lactuca can be incorporated at $5 \%(\mathrm{w} / \mathrm{w})$ in nutribars.
\end{abstract}

Keywords: functional foods, nutraceuticals, nutribars, seaweeds, Ulva lactuca.

\section{Introduction}

Seaweeds are rich sources of bioactive functional food ingredients with different health beneficial biological activities (Plaza et al. 2008, Wijesekara 
et al. 2011). Sri Lanka is an island with approximately $1700 \mathrm{~km}$ long sea-belt, and more than 500 species of seaweeds have been reported. Seaweeds can be categorized in to three major groups such as green (Chlorophyceae), brown (Phaeophyceae), and red (Rhodophyceae) seaweeds according to their pigment distribution. Amongst them, edible green seaweed; sea lettuce (Ulva sp.) has been consumed widely as a sea vegetable in China, Japan, Vietnam, and Korea. Furthermore, seaweeds have been consumed by these Asian people dating back to 100 centuries but they have never found their rightful place in the daily diets of Sri Lankans. Seaweed consumption is sporadically seen near the coastal areas but is still under-exploited. Seaweed-derived ingredients and products are indirectly used commercially. As a natural food, the goodness of seaweeds has to be introduced and utilized.

Sri Lanka contains a diverse species of green seaweeds including Ulva lactuca (sea lettuce), U. faciata, U. intestinalis, Chaetomorpha antenina, and Caulerpa spp. (sea grapes) along the sea-belt of the country (Durairatnam 1961). Unfortunately, relatively less data is available for commercial exploitation of seaweeds of Sri Lanka (Thadhani et al. 2019). Therefore, it is a national need to explore the commercial potential of this valued underutilized marine resource of Sri Lanka. The objectives of the present study were to explore the nutritional composition of underutilized green seaweed $U$. lactuca and develop consumer acceptable nutribars incorporating $U$. lactuca as an alternative protein source.

\section{Material and Methods}

\subsection{Seaweed collection and processing}

The green seaweed (Ulva lactuca) was manually collected during early July, 2017 from Thalaramba beach, Matara, Sri Lanka. The fresh seaweed was thoroughly washed with running tap water and dried at $60{ }^{\circ} \mathrm{C}$ in an electric oven (Leader, Taiwan) for $8 \mathrm{~h}$. Dried seaweed was then grinded and pulverized by using a grinder (Panasonic MX $-337 \mathrm{~N}$, Japan), sieved through 355 micron sieve, and stored under the refrigerator condition $\left(4^{\circ} \mathrm{C}\right)$ until further use.

\subsection{Proximate analysis}

The moisture content of $U$. lactuca seaweed powder was determined according to the oven-dry method (AOAC 925.10, 2005). The protein content of seaweed powder and nutribars were analyzed by Kjeldhal method (AOAC $978.04,2005)$ and the $\mathrm{N}$ factor used in the calculation was 6.25 as generally 
apply in food analysis. The lipid content of seaweed powder was determined according to a modified method (Sanchez-Machado et al. 2004). Briefly, lipids were extracted from $2 \mathrm{~g}$ of the seaweed powder with $14 \mathrm{ml}$ of a mixture of solvents (chloroform: methanol; 2:1, v/v) by subjected to vortex for $2 \mathrm{~min}$. The residue was re-extracted two times and filtered through Whatman No. 41 filter paper. The filtrates were pooled and concentrated to dryness in a water bath followed by measuring the final weight as lipids. In addition, the total ash content of seaweed powder was obtained gravimetrically (AOAC 923.03, 2005).

\subsection{Extraction and Fourier Transform - Infra Red (FT-IR) analysis of crude ulvan}

The polysaccharide fraction crude ulvan was extracted from $U$. lactuca according to a previously published procedure (Jiao et al. 2012) with some modifications. Briefly, $4 \mathrm{~g}$ of dried seaweed powder was treated with methanol at room temperature $\left(28^{\circ} \mathrm{C}\right)$ for $2 \mathrm{~h}$ with magnetic stirring to remove pigments and lipids. The air-dried seaweed residue was then extracted with $100 \mathrm{ml}$ of distilled water at $80{ }^{\circ} \mathrm{C}$ for $3 \mathrm{~h}$. This step was repeated for another two times, followed by filtering through a muslin cloth, and the filtrates were pooled. The pooled filtrates were mixed with two volumes of absolute ethanol and allowed to precipitate the crude polysaccharide at room temperature for overnight. The precipitated crude ulvan was separated and dried in an oven (Leader, Taiwan) at $60{ }^{\circ} \mathrm{C}$ and subjected for FT-IR analysis.

\subsection{Swelling capacity (SWC), water holding capacity (WHC), and oil holding capacity (OHC)}

The SWC of seaweed sample was analyzed by the bed volume technique after equilibrating in excess water (Yaich et al. 2011). Briefly, $1.0 \mathrm{~g}$ of seaweed powder was kept in a $10 \mathrm{ml}$ measuring cylinder and $10 \mathrm{ml}$ of distilled water were added. Then, the mixture was vigorously stirred using a magnetic stirrer and allowed to settle for $20 \mathrm{~h}$ at room temperature $\left(28^{\circ} \mathrm{C}\right)$. The swelling capacity or swelling volume was measured and expressed as volume in $\mathrm{ml}$ of swollen sample per $1 \mathrm{~g}$ of sample. The WHC of the U. lactuca seaweed powder was calculated by the modified centrifugation method reported previously (Yaich et al. 2011). Briefly, the seaweed powder (3 g) was dispersed in $25 \mathrm{ml}$ of distilled water and placed in pre-weighed centrifuge tubes. Then the centrifuge tubes were stirred for $5 \mathrm{~min}$ at the maximum speed and kept at the room temperature for $1 \mathrm{~h}$ followed by centrifugation (3000 $\mathrm{g}$ for $25 \mathrm{~min}$ ). The supernatant was discarded and the water holding capacity of the seaweed was expressed as the $\mathrm{g}$ of water bound per $1 \mathrm{~g}$ of the residual sample in dry form. For the determination of OHC, $1 \mathrm{~g}$ of $U$. lactuca powder 
was mixed with $12 \mathrm{ml}$ of coconut oil in pre-weighed centrifuge tubes and followed the same procedure for WHC.

\subsection{Manufacture of nutribars}

Nutribars were made with Ulva lactuca seaweed powder (0\% as control, $5 \%$ and $10 \%, \mathrm{w} / \mathrm{w}$ ) according to a common formulation (Table 1). Briefly, cowpea, green gram, and soya beans were roasted at $150{ }^{\circ} \mathrm{C}$ and finely grounded and mixed with rice flakes, corn flour, peanuts, and popcorns. The initial mixture (cowpea : green gram : popcorn : corn flour : soy flour : rice flakes : peanut was 12:10:10:8:5:5:5, respectively) was mixed thoroughly with golden syrup and with or without $U$. lactuca powder yielded the initial nutribar base. Then, the sugar was mixed with water and heated under low flame till all the sugar crystals were dissolved. Afterwards, the glucose syrup was added to this sugar syrup, boiled up to $112{ }^{\circ} \mathrm{C}$, and removed from the flame followed by the mixing of previously prepared initial nutribar base. After the thorough mixing, the mixture was poured into moulds (length $\times$ width $\times$ thickness was $8.5 \times 1.5 \times 1.0 \mathrm{~cm}$ ) and allowed to set. Finally, the nutribars were removed from the moulds and packed in triple laminated pouches until further analysis.

Table 1: Formulation of Ulva lactuca incorporated nutribars (for $100 \mathrm{~g}$ of nutribar).

\begin{tabular}{lccc}
\hline Ingredient $(\mathrm{g})$ & $\begin{array}{c}\text { Control (0\% Ulva) } \\
\text { Nutribar }\end{array}$ & $\begin{array}{c}5 \% \text { Ulva added } \\
\text { Nutribar }\end{array}$ & $\begin{array}{c}10 \% \text { Ulva } \\
\text { added } \\
\text { Nutribar }\end{array}$ \\
\hline Nutribar base & 55 & 50 & 45 \\
Sugar & 20 & 20 & 20 \\
Glucose syrup & 10 & 10 & 10 \\
Butter & 05 & 05 & 05 \\
Golden syrup & 05 & 05 & 05 \\
U. lactuca & 00 & 05 & 10 \\
Water & 05 & 05 & 05 \\
\hline
\end{tabular}

\subsection{Analysis of product characteristics of nutribars}

The final quality attributes such as hardness and adhesiveness of the developed nutribars were measured using a laboratory texture analyzer (Brookfield, USA). Moreover, the hardness and adhesiveness were compared with a commercially available nutribar sample. In addition, the color values such as $L^{*}, a^{*}$, and $b^{*}$ values of developed nutribars were determined by using a chromometer (Lovibond ${ }^{\circledR}$ LC1000, Germany). 


\subsection{Sensory evaluation}

The effect of sensory properties such as colour, intensities of aroma and taste, texture, and overall acceptability were evaluated among three types of nutribars by participants using a five-point scale ( 5 for "like extremely" down to 1 for "dislike extremely") to score each attribute. Thirty untrained panelists participated from the Department of Food Science \& Technology, University of Sri Jayewardenepura, Sri Lanka. The three samples were labeled as 874 (Control, 0\% U. lactuca added), 759 (5\% U. lactuca added), and 936 (10\% U. lactuca added). Nonparametric data obtained from this sensory evaluation were statistically analyzed by using Kruskal-Wallis test at 95\% confidence level. The means separations were done by using Mann-Whitney test at 95\% confidence level.

\subsection{Statistical analysis}

All experiments were carried out in triplicate and results were presented as mean \pm standard deviation. The statistical analysis of data was carried out using one-way ANOVA to test the significant difference of each variable $(\mathrm{p}<0.05)$, and followed by performed using the Turkey test by the statistical software MINITAB 17 (Pennsylvania, USA).

\section{Results and Discussion}

\subsection{Proximate composition of Ulva lactuca}

The results of proximate analysis of dried and powdered U. lactuca seaweed samples are presented in the Table 2 . The dried and grinded seaweed powder (final moisture content \%; $15.29 \pm 0.03$ ) contained considerable amount of protein (\% in dry basis; $20.16 \pm 0.16$ ). Therefore, underutilized sea lettuce $U$. lactuca in Sri Lanka has a potential to be introduced as alternative plantderived protein source in the local food industry. The protein content of seaweeds varies and depends on the species, season and environmental growth conditions (Harnedy and FitzGerald 2011; Peinado et al. 2014). For example, the protein content of Palmaria palmata (Rhodophyta) is higher in the winter-spring period than the summer-early autumn period (GallandIrmouli et al. 1999). Generally, brown seaweeds have lesser protein content ( 7 $-16 \%$, dry weight) than red $(21-47 \%, \mathrm{dw})$ and green seaweeds $(10-26 \%$, dw) (Dawczynski et al. 2007; Fleurence, 1999). However, seaweeds may contain non-protein nitrogen $(\mathrm{N}$, such as free nitrates, pigments, nucleic 
acids), resulting in an over estimation of their protein content (which estimated by general N-to-protein conversion factor of 6.25). Therefore, the changes in protein content of $U$. lactuca in Sri Lankan sea waters need to be investigated though Sri Lanka lacks four seasons like sub-tropical countries. The studied $U$. lactuca in the present study contained $1.37 \pm 0.05 \%$ (dry basis) of crude lipids. Generally, seaweeds are low in lipids (1 - 5\%, dry basis) according to the previously published reports (Tabarsa et al. 2012). Seaweeds are rich resources of essential minerals for human nutrition and health. The ash content $(\%)$ of $U$. lactuca was $17.17 \pm 0.62$ and this was in accordance with previously published data for this seaweed species. Moreover, it has been reported that $U$. lactuca surprisingly contains the highest content of iron than some of terrestrial crops such as lettuce, cabbage, carrot, broccoli, and spinach (Tabarsa et al. 2012).

Table 2: Proximate composition of sea lettuce $U$. lactuca from Matara Coast, Sri Lanka.

\begin{tabular}{ll}
\hline Parameter & $\begin{array}{l}\text { Composition } \\
(\mathrm{g} / 100 \mathrm{~g} \text { of dry weight })\end{array}$ \\
\hline Moisture content & $15.29 \pm 0.03$ \\
Crude fiber & $36.78 \pm 1.75$ \\
Crude protein & $20.16 \pm 0.16$ \\
Crude lipid & $01.37 \pm 0.05$ \\
Ash content & $17.17 \pm 0.62$ \\
\hline
\end{tabular}

\subsection{Crude ulvan content}

Ulvan is the major water-soluble sulfated polysaccharide (soluble dietaryfibers) found in green seaweeds of the Order: Ulvales and the common members are Ulva spp. and Enteromorpha spp. (Jiao et al. 2011). The crude ulvan polysaccharide content (\%) obtained in the present study was $17.21 \pm$ 1.70 and this value is notably higher than the cold water and hot water extracted ulvan in previous reports (Jiao et al. 2012; Thanh et al. 2016). The yield and the chemical structure of seaweed polysaccharides differ from species to species and even in the same species the polysaccharide shows some structural differences according to stage of the seaweed life-cycle, anatomy, and geographical location (Black et al. 1965). The ulvan from $U$. lactuca was mainly composed of rhamnose with variable contents of xylose and glucose and trace amounts of galactose and mannose (Thanh et al. 2016). 


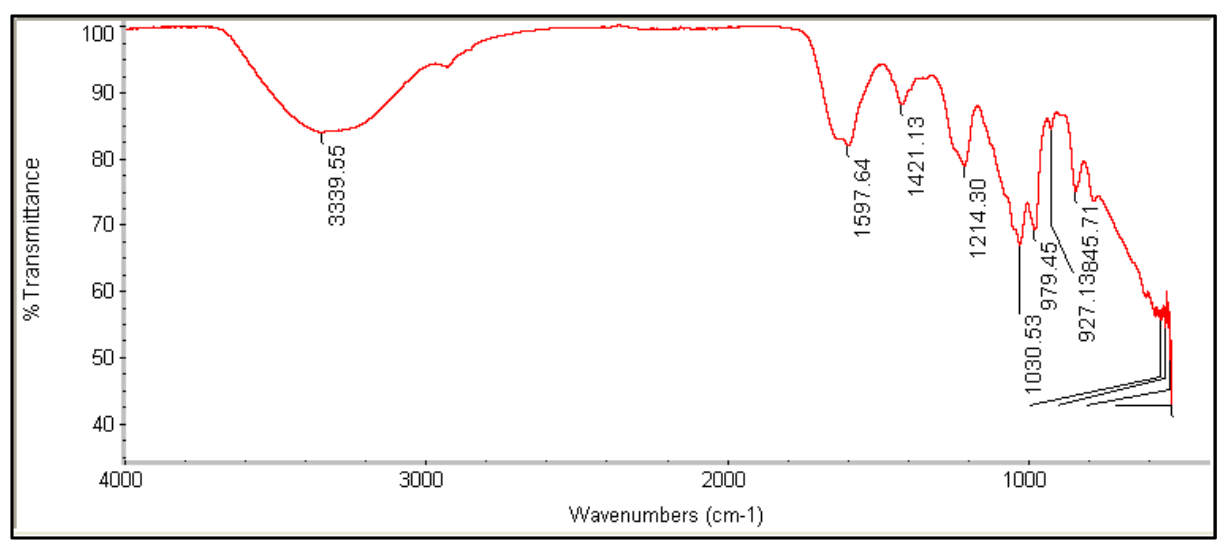

Fig. 1. FT-IR spectrum of the extracted crude ulvan from Ulva lactuca

Current findings demonstrated that ulvan is health beneficial polysaccharide with different biological activities such as anticancer, antioxidant, antihyperlimidemic, and anticoagulant functions makes it suitable for a wide range of applications in the food industry (Kim et al. 2011, Wijesekara et al. 2011). Based on FT-IR analysis (Figure 1), the crude ulvan samples revealed polysaccharides features at about $3339.55 \mathrm{~cm}^{-1}$ ( $v_{\mathrm{O}-\mathrm{H}}$ of $-\mathrm{OH}$ group), around $2950 \mathrm{~cm}^{-1}$ ( $v_{\mathrm{C}-\mathrm{H}}$ of pyranose), $1601 \mathrm{~cm}^{-1}\left(v_{\mathrm{C}=\mathrm{O}}\right.$ of $\left.-\mathrm{COO}\right)$ and $1030 \mathrm{~cm}^{-1}\left(v_{\mathrm{C}-\mathrm{OH}}\right.$ of glycoside). The strong absorption band at about $1214 \mathrm{~cm}^{-1}\left(v_{\mathrm{O}=\mathrm{S}=\mathrm{O}}\right.$ of sulfate) and sharp band at $845.23 \mathrm{~cm}^{-1}\left(v_{\mathrm{C}-\mathrm{o}-\mathrm{S}}\right)$ suggested the presence of sulfate groups and substitution positions. In the current study, due to lack of purified ulvan as the standard sample, a comparison analysis was not carried out. However, the spectrum is similar to spectrums obtained for ulvan in previously published reports (Jiao et al. 2012, Tian et al. 2015, Trivedi et al. 2016).

\subsection{SWC, WHC, and OHC of seaweed powder}

To study the hydration properties of U. lactuca dried seaweed powder, swelling capacity (SWC) and water holding capacity (WHC) were determined at room temperature $\left(28^{\circ} \mathrm{C}\right)$. In the present study, the WHC was $4.39 \pm 0.07 \mathrm{~g}$ of water/g of dry seaweed powder and this value is lower than previously reported (6.66 g of water/g of dry seaweed) for the same seaweed species in another study (Yaich et al. 2011). It has been reported that the WHC of $U$. lactuca powder slightly increases with temperature probably related to the increment of solubility of fibers and proteins (Fleury and Lahaye 1991). The SWC of the $U$. lactuca powder analyzed in the present study was $1.00 \pm 0.10$ $\mathrm{ml} / \mathrm{g}$ of dry seaweed powder and this was higher than previously reported 
(Yaich et al. 2011). Water exists in fibers in three forms; it is bound to the hydrophilic polysaccharides, it is held within the fiber matrix or it is trapped within the cell wall lumen. WHC, determined by the centrifugation method in this study represented all three types of water associated with fibers. Apart from different WHC of fibers, the differences in WHC and SWC among the seaweed samples might be attributed to the different protein conformations and the variations in the number and nature of the water binding sites on protein molecules. These properties can influence the successful incorporation of fiber-enriched ingredients into foods. The OHC of $U$. lactuca powder at room temperature was $2.22 \pm 0.27 \mathrm{~g}$ of oil/g of seaweed powder and this was notably higher than previously reported (1.68 $\mathrm{g}$ of oil/g of seaweed). However, coconut oil was used in this study to determine $\mathrm{OHC}$ since coconut oil is widely applied in cooking purposes of Sri Lanka. Moreover, the OHC of $U$. lactuca is higher than some terrestrial sources such as orange (0.86-1.28 $\mathrm{g} / \mathrm{g}$ dry weight) and peach $(1.02-1.11 \mathrm{~g} / \mathrm{g}$ dry weight) dietary fiber concentrates. The importance of this OHC property is related to the stabilization of foods with high fat content and emulsions, and to the physical entrapment of oil which acts as flavor retainer and increases the mouth-feel of foods. Therefore, $U$. lactuca powder could be a potential functional ingredient to be incorporated in lipid-based foods; for example chocolates.

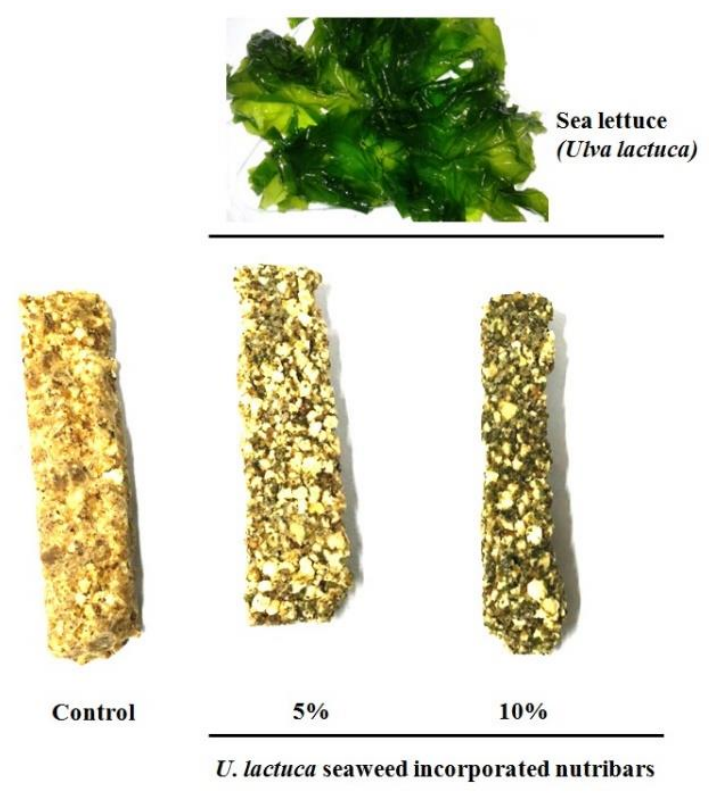

Fig. 2. Sea lettuce Ulva lactuca thalus and incorporated nutribars 


\subsection{Properties of seaweed $U$. lactuca incorporated nutribars}

In the present study, nutribars were developed by incorporating $U$. lactuca seaweed powder at two different ratios ( 5 and 10\%, w/w) and compared with the control ( $0 \%$ of seaweed powder) (Figure 2). According to Kjeldhal analysis, the crude protein contents of control, 5\% U. lactuca added, and $10 \%$ U. lactuca added nutribars were $7.54 \pm 0.15,7.89 \pm 0.03$, and $8.55 \pm 0.38$, respectively. The results have confirmed that the protein content of $10 \% \mathrm{U}$. lactuca added sample showed significantly the highest protein content ( $p \leq$ 0.05 ) of three types of nutribars.

Hardness is the amount of force required to bite through the sample with incisors and adhesiveness is the work necessary to overcome the attractive forces between the surface of the food and the surface of other materials with which the food comes into contact (e.g. tongue, teeth, and palate). According to instrumental texture analysis (Table 3) significant differences in hardness and adhesiveness of nutribar samples were obtained. There was no significant difference of hardness in between control and 5\% U. lactuca added nutribar samples. However, hardness of $10 \%$ U. lactuca added nutribar samples and commercially available nutribars were significantly different from each other. When adding more pulverized seaweed powder, hardness of the nutribar was increased. Hardness of commercially available nutribar was greater than control and 5\% U. lactuca added sample. Decreasing order of adhesiveness of nutribars was $10 \% \mathrm{U}$. lactuca added > control > 5\% U. lactuca added > commercially available sample. Therefore, force required to remove $10 \% U$. lactuca added nutribar from mouth is the highest. Moreover, commercially available nutribar was the lowest. Therefore, required force to remove from mouth is very low. Reason for this is commercially available nutribar was crispy in texture.

Table 3: Texture profile analysis results of control, $U$. lactuca added, and commercial nutribars.

\begin{tabular}{lrrrc}
\hline \multicolumn{1}{c}{ Parameter } & Control & $5 \%$ U. lactuca & $10 \%$ U. lactuca & Commercial \\
\hline Hardness $(\mathrm{g})$ & $1035.0 \pm 62.2^{\mathrm{c}}$ & $1356.0 \pm 281^{\mathrm{c}}$ & $2146.3 \pm 116.9^{\mathrm{a}}$ & $1741.3 \pm 78.9^{\mathrm{b}}$ \\
Adhesiveness $(\mathrm{mJ})$ & $5.09 \pm 1.28^{\mathrm{b}}$ & $2.82 \pm 3.17^{\mathrm{b}, \mathrm{c}}$ & $9.08 \pm 0.51^{\mathrm{a}}$ & $1.11 \pm 0.89^{\mathrm{c}}$ \\
\hline
\end{tabular}

Values for texture profile analysis are means $\pm S D ; n=3$, and means in the same row followed by different letters are significantly different $(p<0.05)$.

The colour analysis results of nutribars were presented in Table 4. Lightness of $5 \% \mathrm{U}$. lactuca added nutribars had significantly the highest lightness compared to other two bars. Lightness of $10 \%$ U. lactuca added sample had 
the significantly lowest lightness. Powdered seaweed $U$. lactuca contains very low lightness value and dark colour appears when drying the raw seaweed samples due to the degradation of chlorophyll pigments (Ali et al.2014).

Table 4: Mean chroma meter colour values for control, 5\%, and $10 \%$ U. lactuca added nutribars.

\begin{tabular}{lccc}
\hline Type of nutribar & $L^{*}$ & $a^{*}$ & $b^{*}$ \\
\hline Control & $45.30 \pm 1.32^{\mathrm{a}}$ & $11.33 \pm 0.67^{\mathrm{a}}$ & $19.23 \pm 0.91^{\mathrm{a}}$ \\
$5 \%$ Ulva added & $57.43 \pm 1.08^{\mathrm{b}}$ & $4.87 \pm 1.25^{\mathrm{b}}$ & $20.80 \pm 0.89^{\mathrm{a}}$ \\
$10 \%$ Ulva added & $41.37 \pm 1.30^{\mathrm{c}}$ & $2.70 \pm 0.10^{\mathrm{c}}$ & $15.53 \pm 0.59^{\mathrm{b}}$ \\
\hline
\end{tabular}

Values for colour analysis are means $\pm \mathrm{SD} ; \mathrm{n}=3$, and means in the same column followed by different letters are significantly different $(p<0.05)$.

The negative $a^{*}$ values indicate the closeness to green and positive values indicate the closeness to red. The results showed nutribars are significantly different in $a^{*}$ value and the control was closeness to red colour followed by $5 \%$ and $10 \%$ U. lactuca added nutribars. Negative $b^{*}$ values indicate closeness to blue colour and positive values indicate the closeness to yellowness. According to results, all three types of nutribars were shown to be as close to yellow than blue. The yellowness of control nutribars and 5\% U. lactuca added samples were not significantly different and significantly the lowest $b^{*}$ value was shown by $10 \%$ U. lactuca added nutribars.

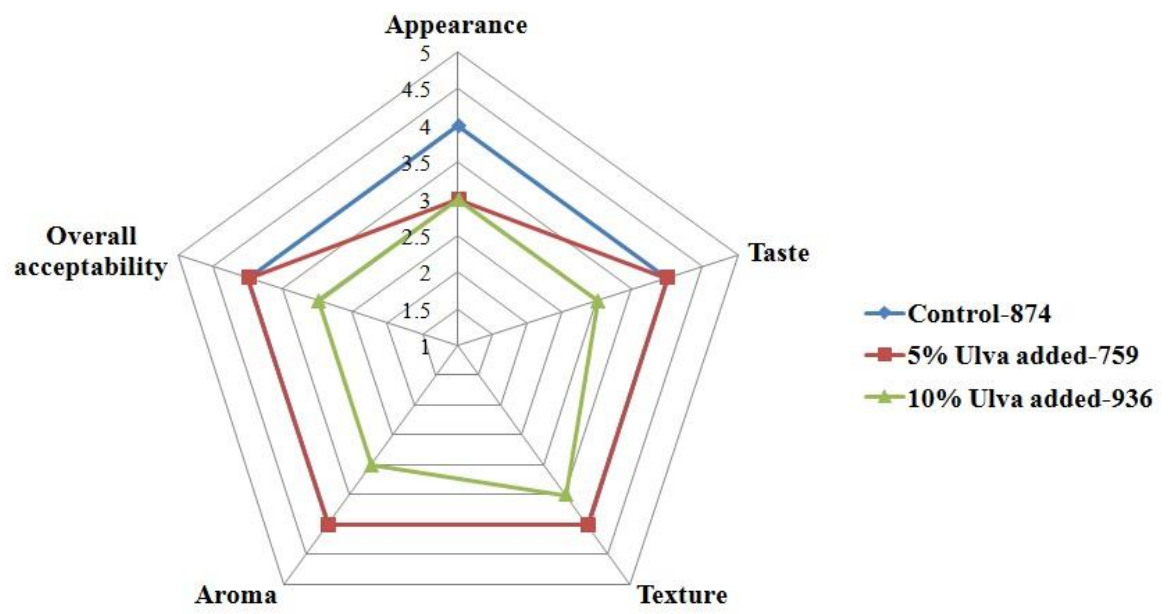

Fig. 3. Web diagram of the average rank of three nutribars from sensory analysis 
The effect of sensory properties such as colour, intensity of $U$. lactuca aroma, intensity of $U$. lactuca taste, texture and overall acceptability was evaluated among three different nutribars (Figure 3). Appearance of each and every sample is significantly different $(\mathrm{p} \leq 0.05)$ from each other. There was no significant different $(p \leq 0.05)$ between aroma of 874 sample and 759 sample. However, there was a significant difference in between 874 and 936 samples as well as in between 759 and 936 samples were obtained. As observed in the present study, except for the appearance, all other sensory attributes were similar for 874 (control) and 759 (5\% U. lactuca added) nutribars. The green colour and the aroma from the seaweed were the reason for the less consumer acceptance for $10 \%$ U. lactuca added nutribars.

\section{Conclusions}

The results obtained in the present study clearly demonstrated that the edible green seaweed $U$. lactuca (sea lettuce) from Matara, Sri Lanka is rich in soluble dietary fiber, proteins, and minerals. This seaweed has a potential to be introduced to the food industry to develop novel functional food products since it has acceptable functional properties such as swelling capacity, water holding, and oil holding capacities. Moreover, seaweed-incorporated food products have a leading consumer trend in the Western countries. Hence, promoting these seaweed-added foods will be a new resource to generate an additional income to the coastal community as well as foreign income to the country. Collectively, it can be concluded that the incorporation of underutilized $U$. lactuca in nutribars is possible and acceptable at $5 \%(\mathrm{w} / \mathrm{w})$ ratio. However, addition of aroma masks can be recommended when incorporating this seaweed in higher ratios to develop new food products.

\section{Acknowledgements}

This research was supported by the University of Sri Jayewardenepura, Sri Lanka. Research assistance in FT-IR analysis by Dr. Asitha Cooray and team, Instrument Centre at Faculty of Applied Sciences, University of Sri Jayewardenepura is gratefully acknowledged. Technical assistance in proximate analysis from Ms. Hasanthika Sandarenu, and comments of two anonymous reviewers are acknowledged.

\section{References}

Ali MA, Yusof YA, Chin NL, Ibrahim MN, Basra SMA. 2014. Drying kinetics and colour analysis of Moringa oleifera leaves. Agriculture \& Agricultural Science Procedia 2: 394400.

Black WAP, Blakemore WR, Colquhoun JA, Dewar ET. 1965. The evaluation of some red marine algae as a source of carrageenan and of its $\kappa$ - and $\lambda$-components. Journal of the 
Science of Food \& Agriculture 16(10): 573-585.

Dawczynski C, Schubert R, Jahreis G. 2007. Amino acids, fatty acids, and dietary fibre in edible seaweed products. Food Chemistry 103: 891-899.

Durairatnam M. 1961. Contribution to the study of marine algae of Ceylon. Bulletin of Fisheries Resources Station, Ceylon 10:5-117.

Fleurence J. 1999. Seaweed proteins: biochemical, nutritional aspects and potential uses. Trends in Food Science \& Technology 10(1): 25-28.

Fleury N, Lahaye M. 1991. Chemical and physico-chemical characterisation of fibres from Laminaria digitata (kombu breton): A physiological approach. Journal of the Science of Food \& Agriculture 55(3): 389-400.

Galland-Irmouli AV, Fleurence J, Lamghari R, Lucon, M, Rouxel C, Barbaroux O, Bronowicki JP, Villaume C, Gueant JL. 1999. Nutritional value of proteins from edible seaweed Palmaria palmata (dulse). The Journal of Nutritional Biochemistry 10(6): 353-359.

Harnedy PA, FitzGerald R. 2011. Bioactive proteins, peptides, and amino acids from macroalgae. Journal of Phycology 47(2): 218-232.

Jiao G, Yu G, Wang W, Zhao X, Zhang J, Ewart SH. 2012. Properties of polysaccharides in several seaweeds from Atlantic Canada and their potential anti-influenza viral activities. Journal of Ocean University of China 11(2): 205-212.

Jiao G, Yu G, Zhang J, Ewart HS. 2011. Chemical structures and bioactivities of sulfated polysaccharides from marine algae. Marine Drugs 9(2): 196-223.

Kim SK, Pangestuti R, Rahmadi P. 2011. Sea lettuces: Culinary uses and nutritional value. Advances in Food \& Nutrition Research 64: 57-70.

Peinado I, Girón J, Koutsidis G, Ames JM. 2014. Chemical composition, antioxidant activity and sensory evaluation of five different species of brown edible seaweeds. Food Research International 66: 36-44.

Plaza M, Cifuentes A, Ibanez E. 2008. In the search of new functional food ingredients from algae. Trends in Food Science \& Technology 19(1): 31-39.

Sanchez-Machado DI, Lopez-Cervantes J, Lopez-Hernandez J, Paseiro-Losada P. Fatty acids, total lipid, protein and ash contents of processed edible seaweeds. Food Chemistry 85(3): 439-444.

Tabarsa M, Rezaei M, Ramezanpour Z, Waaland JR. 2012. Chemical compositions of the marine algae Gracilaria salicornia (Rhodophyta) and Ulva lactuca (Chlorophyta) as a potential food source. Journal of the Science of Food \& Agriculture 92(12): 2500-2506.

Thadhani VM, Lobeer A, Zhang W, Irfath M, Su P, Edirisinghe N, Amaratunge G. 2019. Comparative analysis of sugar and mineral content of Sargassum spp. collected from different coasts of Sri Lanka. Journal of Applied Phycology, Accepted manuscript, doi.org/10.1007/s10811-019-01770-4

Thanh TTT, Quach TMT, Nguyen TN, Luong DV, Bui ML, Tran TTV. 2016. Structure and cytotoxic activity of ulvan extracted from green seaweed Ulva lactuca. International Journal of Biological Macromolecules 93(A): 695-702.

Tian H, Yin X, Zheng Q, Zhu L, Chen J. 2015. Isolation, structure, and surfactant properties of polysaccharides from Ulva lactuca L. from South China Sea. International Journal of Biological Macromolecules 79: 577-582.

Trivedi N, Baghel RS, Bothwell J, Gupta V, Reddy CRK, Lali AM, Jha B. 2016. An ingrated process for the extraction of fuel and chemicals from marine macroalgal biomass. Scientific reports 6: 30728, doi: 10.1038/srep30728

Wijesekara I, Pangestuti R, Kim SK. 2011. Biological activities and potential health benefits of sulfated polysaccharides derived from marine algae. Carbohydrate Polymers 84(1): 1421.

Yaich H, Garna H, Besbes S, Paquot M, Blecker C, Attia H. 2011. Chemical composition and functional properties of Ulva lactuca seaweed collected in Tunisia. Food Chemistry 128(4): 895-901. 